\title{
Flow cytometry in diagnosis and management of large fetomaternal haemorrhage
}

\author{
P R E Johnson, R C Tait, E B Austin, K H Shwe, D Lee
}

\begin{abstract}
Aims-To evaluate an indirect immunofluorescence flow cytometry technique in a series of patients with large fetomaternal haemorrhage (FMH).

Methods-Patient samples identified by Kleihauer testing in local laboratories as having FMH >4 ml were sent for flow cytometric analysis. In a proportion of cases the mothers received anti-D immunoglobulin prophylaxis according to the flow cytometer estimate of FMH volume.

Results-Forty three cases of FMH were studied prospectively. The correlation between Kleihauer and flow cytometry results was poor. In $38(88 \%)$ cases the size of FMH quantitated by flow cytometry was lower than that estimated using the Kleihauer technique. In $13(30 \%)$ cases no Rh D immunoglobulin positive cells were detected by flow cytometry. Centralised review of the original Kleihauer films using a calibrated microscope resulted in improved, but still suboptimal correlation with flow cytometry results. In 15 cases anti-D immunoglobulin was given according to the flow cytometer estimation of FMH size, resulting in a $58 \%$ reduction in the amount of anti-D immunoglobulin given. None of the patients were immunised when tested six months later.

Conclusions-Flow cytometry is helpful for the accurate quantitation and management of patients with large FMH and in cases where the presence of maternal haemoglobin $F$ containing cells renders the Kleihauer technique inaccurate. Worthwhile reductions in the use of anti$D$ immunoglobulin can be achieved.

(f Clin Pathol 1995;48:1005-1008)
\end{abstract}

Keywords: Kleihauer technique, flow cytometry, fetomaternal haemorrhage.

Manchester Blood

Centre,

Plymouth Grove,

Manchester M13 9LL

P R E Johnson

R C Tait

E B Austin

K H Shwe

D Lee

Correspondence to:

Dr P R E Johnson,

Department of Clinical

Haematology, Manchester

Royal Infirmary, Oxford

Road, Manchester M33

9WL.

Accepted for publication 1 June 1995 mer of red cells in a low power microsco and the difficulty of classifying cells of intermediate staining. Furthermore, the Kleihauer test is unable to differentiate between fetal red cells and adult haemoglobin F containing cells which may be present in women with sickle cell and thalassaemic syndromes and in up to $25 \%$ of normal women in the second trimester of pregnancy. ${ }^{2}$ Descriptions of the Kleihauer test method vary between sources and therefore it is not surprising that recent audits have revealed wide variations between laboratories. ${ }^{34}$

The present policy in the UK is that all $\mathrm{Rh}$ $D$ negative women giving birth to a $R h D$ positive child receive $500 \mathrm{IU}$ of anti-D immunoglobulin which is sufficient to neutralise up to $4 \mathrm{ml}$ of fetal red cells. ${ }^{56}$ A Kleihauer screening test is performed in all such cases to detect the $1 \%$ of women who have a bleed larger than $4 \mathrm{ml}^{7}$ In these cases the Kleihauer test is used to quantify the haemorrhage and determine the additional dose of anti-D immunoglobulin. Cases with large bleeds are monitored for the disappearance of haemoglobin $\mathrm{F}$ containing cells using the Kleihauer test and for the presence of free anti-D in maternal serum. ${ }^{5}$

We have evaluated a flow cytometry technique for quantitating $\mathrm{FMH}$ in which fetal cells are detected by their expression of the Rh $D$ antigen. The method has been evaluated in a series of large FMH and compared with the Kleihauer technique.

\section{Methods}

A two stage technique reported previously ${ }^{89}$ was modified as follows: red cells from the maternal EDTA sample were washed four times in normal saline then centrifuged at $3000 \mathrm{rpm}$ for two minutes. Packed cells $(5 \mu \mathrm{l})$ were incubated with $100 \mu \mathrm{l}$ anti-D serum $(70 \mathrm{IU} / \mathrm{ml})$ for 30 minutes at $37^{\circ} \mathrm{C}$. The cells were washed four times in normal saline and were then incubated with $100 \mu$ goat anti-human Fab IgG immunoglobulin (diluted 1 in 50 and labelled with fluorescein isothiocyanate (FITC)) (Sera-lab, Crawley Down, Sussex, UK) for 30 minutes at $37^{\circ} \mathrm{C}$. The cells were washed twice in normal saline, re-suspended in $2 \mathrm{ml}$ normal saline and analysed for green fluorescence using a Cytoron Absolute flow cytometer (Ortho Diagnostics, High Wycombe, UK), with 65000 cells being counted.

As a positive control, mixtures of $\mathrm{Rh} D$ positive cells in $\mathrm{Rh} \mathrm{D}$ negative blood at varying percentages were included with each analysis. For negative controls, $\mathrm{Rh} \mathrm{D}$ positive and negative red cells were incubated with $A B$ serum instead of anti-D in the first incubation.

The volume of the FMH was calculated by multiplying the percentage of $\mathrm{Rh} \mathrm{D}$ positive 
Table 1 Results of flow cytometric analysis of prepared dilutions of $R h D$ positive cells in $R h D$ negative red cells

\begin{tabular}{|c|c|c|c|c|c|}
\hline \multirow[b]{2}{*}{ Percentage $R h D$ positive } & \multicolumn{5}{|c|}{ Flow cytometer result } \\
\hline & Mean & Maximum & Minimum & Median & $S D$ \\
\hline 100 & $98 \cdot 0$ & 99.9 & 92.0 & $99 \cdot 0$ & $2 \cdot 154$ \\
\hline 50 & $52 \cdot 2$ & 63.4 & $43 \cdot 4$ & $53 \cdot 6$ & 6.058 \\
\hline 10 & $10 \cdot 5$ & 14.8 & $8 \cdot 3$ & $10 \cdot 2$ & 1.732 \\
\hline 5 & 5.9 & 8.0 & $4 \cdot 1$ & $5 \cdot 7$ & 1.054 \\
\hline 1 & $1 \cdot 2$ & $2 \cdot 0$ & 0.8 & $1 \cdot 2$ & 0.259 \\
\hline 0.5 & $0 \cdot 6$ & 0.9 & $0 \cdot 3$ & 0.7 & $0 \cdot 108$ \\
\hline 0.4 & 0.5 & 0.7 & $0 \cdot 3$ & 0.5 & 0.109 \\
\hline 0.3 & 0.4 & 0.5 & $0 \cdot 3$ & 0.4 & 0.075 \\
\hline 0 & 0.04 & $0 \cdot 1$ & 0 & 0 & 0.050 \\
\hline
\end{tabular}

$0.3 \%$ corresponds to a FMH of $5 \cdot 4$ fetal red cells. $r=0.998 ; r^{2}=0.996$.

cells detected by flow cytometry by 1800 (assuming a red cell volume of $1800 \mathrm{ml}$ in a pregnant woman at term). ${ }^{10}$

Haematology laboratories in the northwest region of England were invited to send maternal EDTA samples in cases where the Kleihauer test suggested a FMH of greater than $4 \mathrm{ml}$. Anti-D immunoglobulin was administered according to the FMH volume, estimated by flow cytometry, with 125 IU recommended for each $\mathrm{ml}$ of fetal red cells. Subsequent monitoring was carried out according to local laboratory practice and further anti-D immunoglobulin was given if follow up Kleihauer tests at 48 hours showed the presence of haemoglobin $F$ containing cells in the absence of free anti-D immunoglobulin in the maternal serum.

\section{Results}

Excellent differentiation was achieved between $R h D$ positive and negative red cells. Dilutions of $R h D$ positive cells in $R h D$ negative cells revealed the limit of sensitivity of the technique to be $0 \cdot 1 \%$, corresponding to a FMH of $1.8 \mathrm{ml}$. The results of varying dilutions of $R h D$ positive red cells in separately prepared dilutions are shown in table 1 . To ensure that fetal Rh D positive red cells were detected as reliably as adult cells, similar dilutions were made using fetal $R h D$ positive cells in adult $R h D$ negative cells with identical results (not shown).

Over a 12 month period, 43 maternal samples were received from 14 laboratories in which the Kleihauer test suggested a FMH in excess of $4 \mathrm{ml}$ fetal red cells. Kleihauer results ranged from 4 to $254 \mathrm{ml}$ with a mean of $35.5 \mathrm{ml}$ and median of $12 \mathrm{ml}$. The correlation between the Kleihauer test and the flow cytometry results $(r=0 \cdot 714)$ is illustrated in fig 1 . To compare results, the Kleihauer test and the flow

Table 2 Survey of the procedures for performing the Kleihauer test

\begin{tabular}{lc}
\hline Procedure & Number $(n=17)$ \\
\hline Use of a standard operating procedure & 14 \\
Use of a microscope with calibrated field size & 2 \\
Objective lens power & 10 \\
$\times 10$ & 5 \\
$\times 40$ & 2 \\
Other & 17 \\
Use of positive control preparation & 8 \\
Use of negative control preparation & 3 \\
Quantitation of FMH in large bleeds & 14 \\
by fetal:adult ratio & \\
by count of positive cells in 50 low power fields & 10 \\
Formula for calculation of anti-D dosage & 6 \\
cells 50 low power fields $\times 2 \cdot 5$ & 1 \\
cells 50 low power fields $\times 3$ & \\
cells 50 low power fields $\times 5$ & \\
\hline
\end{tabular}

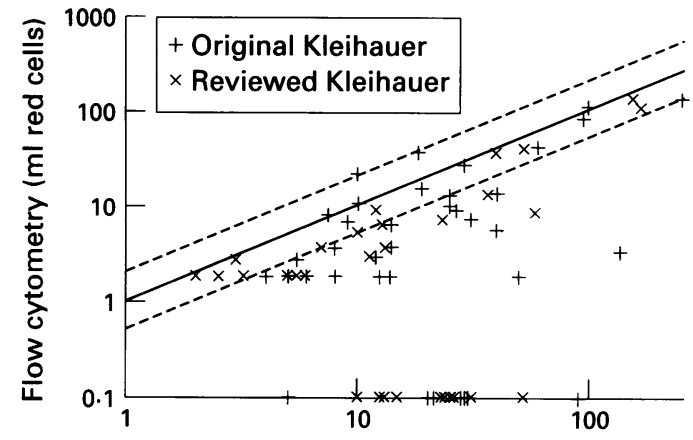

Original and reviewed Kleihauer ( $\mathrm{ml}$ red cells)

Figure 1 Correlation between results obtained using the original and reviewed Kleihauer tests, and on flow cytometry. The dotted lines indicate 50 and $200 \%$ of the Kleihauer result. Original Kleihauer test, $r=0.714 ; r^{2}=$ 0.509 . Reviewed Kleihauer test, $r=0.915 ; r^{2}=0.837$.

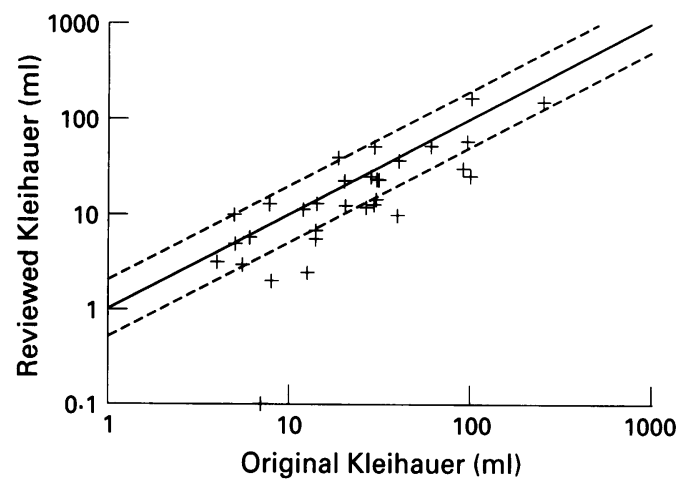

Figure 2 Correlation between the original and reviewed Kleihauer test results. The dotted lines indicate 50 and $200 \%$ of the original Kleihauer test result; $r=0 \cdot 810 ; r^{2}=$ 0.656 .

cytometry results were regarded as being in agreement when the flow cytometry results were within $50-200 \%$ of the Kleihauer test, as shown by the dashed lines in fig 1 . Despite this rather liberal definition, only $26 \%(11 / 43)$ of samples were in agreement. In one case the result on flow cytometry was larger than that estimated by the Kleihauer test and in $31(72 \%)$ cases the Kleihauer test result was larger than that obtained on flow cytometry. In $13(30 \%)$ cases no $\mathrm{Rh} \mathrm{D}$ positive cells were detected by flow cytometry.

In view of the wide variation in results, a survey of Kleihauer methods in 17 hospitals in the region was performed and compared with the guidelines produced by the Association of Clinical Pathologists. ${ }^{11}$ Wide variability in practice was observed, as shown in table 2 . 
Table 3 Patients dosed according to flow cytometer estimate of FMH volume $(n=15)$

\begin{tabular}{|c|c|c|c|c|c|c|}
\hline $\begin{array}{l}\text { Patient } \\
\text { number }\end{array}$ & $\begin{array}{l}\text { FMH volume } \\
\text { (original Kleihauer) }\end{array}$ & $\begin{array}{l}\text { FMH volume } \\
\text { (flow cytometry) }\end{array}$ & $\begin{array}{l}\text { Vol. treated by } \\
\text { anti-D given }(\mathrm{ml})\end{array}$ & $\begin{array}{l}\text { Free anti-D } \\
\text { at } 48 \text { hours }\end{array}$ & $\begin{array}{l}\text { Anti-D } \\
\text { at six months }\end{array}$ & $\begin{array}{l}\text { Volume } \\
\text { untreated }(\mathrm{ml})^{*}\end{array}$ \\
\hline $\begin{array}{r}1 \\
2 \\
3 \\
4 \\
5 \\
5 \\
6 \\
7 \\
8 \\
9 \\
10 \\
11 \\
12 \\
13 \\
14 \\
15\end{array}$ & $\begin{array}{r}254 \\
100 \\
95 \\
90 \\
40 \\
30 \\
29 \\
28 \\
20 \\
20 \\
19 \\
14 \\
12 \\
8 \\
5\end{array}$ & $\begin{array}{c}130 \\
0 \\
83 \\
0 \\
5 \cdot 4 \\
0 \\
0 \\
0 \\
0 \\
0 \\
15 \cdot 3 \\
6.3 \\
2.9 \\
1.8 \\
1.8\end{array}$ & $\begin{array}{r}144 \\
20 \\
80 \\
4 \\
8 \\
4 \\
8 \\
4 \\
4 \\
4 \\
16 \\
8 \\
4 \\
4 \\
4\end{array}$ & $\begin{array}{l}\mathrm{Y} \\
\mathrm{Y} \\
\mathrm{Y} \\
\mathrm{Y} \\
\mathrm{Y} \\
\mathrm{Y} \\
\mathrm{Y} \\
\mathrm{Y} \\
\mathrm{Y} \\
\mathrm{Y} \\
\mathrm{N}^{* *} \\
\mathrm{Y} \\
\mathrm{Y} \\
\mathrm{Y} \\
\mathrm{Y}\end{array}$ & $\begin{array}{l}\text { Neg } \\
\text { Neg } \\
\text { Neg } \\
\text { Neg } \\
\text { Neg } \\
\text { Neg } \\
\text { Neg } \\
\text { Neg } \\
\text { Neg } \\
\text { Neg } \\
\text { Neg } \\
\text { Neg } \\
\text { Neg }\end{array}$ & $\begin{array}{r}110 \\
80 \\
15 \\
86 \\
32 \\
26 \\
21 \\
24 \\
16 \\
16 \\
3 \\
6 \\
8 \\
4 \\
1\end{array}$ \\
\hline
\end{tabular}

* Relative to original Kleihauer estimate.

** Patient received a further 500 IU anti-D according to study protocol.

In 31 cases the original Kleihauer films were reviewed centrally using a calibrated microscope. The correlation between the corrected and original Kleihauer tests is shown in fig 2. Fifteen (48\%) of the 31 corrected Kleihauer tests are within $50-200 \%$ of the original results $(r=0 \cdot 810)$. The correlation between the corrected Kleihauer test and the flow cytometery results is illustrated in fig 1 . Results were in agreement in $12(39 \%)$ of the 31 cases ( $r=$ 0.915).

In 13 cases $R h$ positive cells were not detected by flow cytometry despite having a sizeable FMH as measured by the Kleihauer test (range 5-100 ml fetal red cells). Further investigation of these cases revealed that four were due to poor Kleihauer preparations, three were due to mid-trimester maternal haemoglobin $\mathrm{F}$, two resulted from adult haemoglobin F syndromes confirmed post-natally, two were cases of raised maternal haemoglobin $F$ at delivery which resolved after six months, possibly persistent mid-trimester increases, and two were caused by probable $\mathrm{Rh} D$ negative fetuses.

Fifteen cases were treated according to the flow cytometer estimate of FMH volume. Results in these patients are given in table 3.

\section{Discussion}

The Kleihauer acid elution test is widely used in the UK for the detection and quantitation of FMH. While the test is very sensitive, its accuracy in quantitating larger bleeds, particularly those over $4 \mathrm{ml}$ which are not adequately treated with the standard dose of antiD immunoglobulin, is a cause for concern. ${ }^{34}$ Although the test has some inherent inaccuracies, ${ }^{6}$ the major problems seem to be caused by a lack of consistency in the methods used by various laboratories ${ }^{1611}$ and inaccurate microscope calibration. Hopefully the recent introduction of a national external quality assurance scheme for the Kleihauer test will result in improved standardisation and results. ${ }^{7}$

The flow cytometry technique differentiated clearly between $R h D$ positive and negative cells, showed good correlation in dilution experiments and had a sensitivity of $0.1 \%$ in accordance with previous studies. ${ }^{12}$ Analysis took about 75 minutes, which could shortened further by incorporating a one stage procedure utilising directly conjugated monoclonal anti$D$ reagents (for example, FITC-BRAD-1, IGBRL, UK).

While the Kleihauer test is a simple, sensitive and cost effective technique for detecting patients with a FMH below $4 \mathrm{ml}$, flow cytometry offers several advantages in patients with larger FMH; 65000 cells are assessed individually using the flow cytometer and several sources of inherent errors in the Kleihauer test are eliminated. Raised maternal haemoglobin $\mathrm{F}$ concentrations render the Kleihauer test inconclusive, whereas the flow cytometer detects potentially immunising $R h \mathrm{D}$ positive cells even in cases where the $\mathrm{Rh}$ status of the fetus is not known. ${ }^{1314}$ In $88 \%$ of cases the FMH detected using flow cytometry was lower than that estimated by the Kleihauer test. This observation is in accord with the general view that the Kleihauer test frequently overestimates the size of FMH. This was clearly demonstrated in the FMH of $254 \mathrm{ml}$ estimated by the Kleihauer test, which exceeds the entire red cell volume of a fetus and placenta.

In our study of 15 patients treated with anti-D immunoglobulin according to the FMH estimated by flow cytometry, significant reductions in the dose of anti-D immunoglobulin needed were achieved, with free anti-D immunoglobulin being detected at 48 hours in all but one case. In the one patient in whom anti$\mathrm{D}$ immunoglobulin was not detected, implying inadequate dosing, further study showed that the anti-D immunoglobulin was administered in two doses separated by 24 hours and that the 48 hour screen for anti-D immunoglobulin was performed approximately 12 hours after the second injection. It is possible that this was too early for adequate absorption, but the study protocol required the administration of further anti-D immunoglobulin in this situation. No patients were immunised when tested six months later. Improved accuracy in the quantitation of large FMH results in the more rational use of anti-D immunoglobulin.

In conclusion, flow cytometry may be helpful for the accurate quantitation and management of patients with large FMH and in cases where the presence of maternal haemoglobin F containing cells renders the Kleihauer technique 
inaccurate. While a well standardised Kleihauer test is appropriate as a screening test for $\mathrm{FMH}$, studies to assess the role of flow cytometry for detecting $\mathrm{FMH}$ are warranted.

The authors thank all those who participated in the study.

1 Waters AH, Lloyd EE. Laboratory aspects of blood transfusion. In: Dacie JV, Lewis SM, eds. Practical haematology. 7th edn. Edinburgh: Churchill Livingstone, 1991:115-24; 455-76.

2 Popat N, Wood WG, Weatherall DJ, Turnbull AC. Pattern of maternal F-cell production during pregnancy. Lancet 1977;ii:377-9.

3 MacLennan S, Flanagan P. Prophylaxis with anti-D immunoglobulin. BMF 1994;308:203.

4 Duguid JKM, Bromilow I. Value of Kleihauer testing after administration of anti-D immunoglobulin. $B M \mathcal{F}^{1994 \text {; }}$ 309:240.

5 National Blood Transfusion Service Immunoglobulin Working Party. Recommendations for the use of anti-D iming Party. Recommendations for the use of anti-D

6 Mollison PL, Engelfriet CP, Contreras M. In: Blood transfusion in clinical practice. 9 th edn. Oxford: Blackwell Scientific Publications, 1993.
7 Letsky EA, De Silva M. Preventing Rh immunisation. $B M \mathcal{F}$ 1994;309:213-14.

8 Cupp JE, Leary JF, Cernichiari E, Wood J, Doherty RE Rare-event analysis methods for the detection of foetal red blood cells in maternal blood. Cytometry 1984;5:138-44.

9 Medearis AL, Hensleigh PA, Parks DR, Herzenberg LA. Detection of foetal erythrocytes in maternal blood post partum with fluorescence-activated cell sorter. Am 7 Obstet Gynecol 1984;148:290-5.

10 Wynn R, Dixon S, Al-Ismail SA, Jones JG, Fisher J, Hoy $\mathrm{T}$, et al. Flow cytometric determination of pre-transfusion $\mathrm{T}$, et al. Flow cytometric determination of pre-transfusion red cell volume in foetuses and neonates requiring trans-
fusion based on $\mathrm{RhD}+$ dilution by transfused $\mathrm{D}$-cells. $\mathrm{Br}$ fusion based on $\mathrm{RhD}+$ dilutio

11 Wagstaff W. Broadsheet No. 90. Practical aspects of anti-D prophylaxis of haemolytic disease of the newborm. London: Association of Clinical Pathologists, 1978.

12 Bayliss KM, Kueck BD, Johnson ST, Fueger JT, McFadden PW, Mikulski D, et al. Detecting foetomaternal haemorrhage: A comparison of five methods. Transfusion 1991; 31:303-7.

13 Patton WN, Nicholson GS, Sawers AH, Franklin IM, Ala FA, Simpson AW. Assessment of foetal-maternal haemorrhage in mothers with hereditary persistence of foetal orrhage in mothers with hereditary persisten
haemoglobin. $\mathcal{F}$ Clin Pathol 1990;43:728-31.

14 Goldman M, Blajchman MA, Ali MAM. Overestimation of foetomaternal haemorrhage by the acid-elution technique in mothers with $\beta$-thalassaemia minor. Transfus Med 1991; 1:129-32. 